\title{
Sources of variation in quality of South African beef: Case studies in relation to the red meat classification system
}

\author{
P.E. Strydom ${ }^{1}$, L. Frylinck ${ }^{1}$, S.M. van Heerden ${ }^{1}$, M. Hope-Jones ${ }^{1}$, A. Hugo ${ }^{2}$, E.C. Webb ${ }^{3}$, \\ E. Moholisa ${ }^{1}$, B.E. Liebenberg ${ }^{2}$ \& O.C. Sehoole ${ }^{1}$ \\ ${ }^{1}$ ARC-Animal Production Institute, Private Bag X2, Irene, 0062. South Africa \\ ${ }^{2}$ Department of Microbial, Biochemical and Food Biotechnology, University of Free-State, Bloemfontein, South Africa \\ ${ }^{3}$ Department of Animal and Wild Life Science, University of Pretoria, Pretoria, South Africa.
}

(Received 27 November 2014; Accepted 14 April 2015; First published online 4 August 2015)

Copyright resides with the authors in terms of the Creative Commons Attribution 2.5 South African Licence.
See: http://creativecommons.org/licenses/by/2.5/za
Condition of use: The user may copy, distribute, transmit and adapt the work, but must recognise the authors and the South African
Journal of Animal Science.

\begin{abstract}
The South African classification system describes beef carcasses in regard to visual fat cover, conformation and age by dentition. Animal age provides a fairly accurate description of expected eating quality in regard to tenderness in an industry where other sources of variation in tenderness are limited. Since deregulation in the beef industry in the 90s many changes have occurred in all parts of the value chain. This paper presents a number of case studies that focussed on the sources of variation in meat quality, but in particular on sources of changes in meat tenderness over the past two decades. These sources include feeding regime, the use of beta agonists, post mortem ageing and electrical stimulation. In some studies these factors are integrated with age or interactions among two or more of these factors are investigated.
\end{abstract}

Keywords: Age, beef, classification, dentition, grading

\#Corresponding author: pstrydom@arc.agric.za

\section{Introduction}

Smith et al. (2008) described the consumer process in terms of a 'customer' (person who purchases) whose preference is influenced by appearance characteristics (e.g. relative proportions of muscle, fat and bone, amount of marbling, colour of fat and lean, freedom from defects). The quality of cooked meat is then evaluated by a 'consumer' in terms of palatability characteristics (e.g. flavour, juiciness, tenderness). Therefore both yield factors (fat, bone, meat) and eating quality will influence consumer preferences, but most consumer surveys suggest that eating quality (defined by most consumers simply as 'taste') is a primary driver of food purchase decisions (Quinn, 1999; Shook et al., 2008).

While classification or grading is intended to provide a common language for all role players in the value chain, to serve as market indicator and provide production guidelines for producers, to facilitate trade and promote a basis for quality, it ultimately serves to provide a product that satisfies the consumer even though the consumer may not have first-hand knowledge of the systems (AHDB Industry Consulting, 2008). Per definition, classification describes all the scores or measurements for important value traits according to a common descriptive language. The carcass is then presented to the wholesaler or retailer listing all the attributes that have been evaluated. Grading is defined as the placing of different values on several carcass characteristics and using different combinations of these characteristics to develop a grade for pricing purposes, depending on the market and requirements of traders and consumers. Generally this involves ranking carcasses in a hierarchy according to the traits which are of importance in relation to trade and consumer preferences.

\section{A short history of grading and classification in South Africa}

The criteria for yield parameters in the current classification system are simply the estimations of fat cover and roundness or conformation of the carcass. This aspect of the classification system will not be discussed further except to conclude that meat yield can be fairly accurately predicted if weight of the carcass, conformation score and fat score are known. Strydom \& Smith (2005) determined that the linear 
prediction model, $\mathrm{Y}=-1.43+0.254 \mathrm{x}_{1}-0.811 \mathrm{x}_{2}+0.801 \mathrm{x}_{3}$, could be used to predict lean meat yield $(\mathrm{kg})$ with a coefficient of determination $\left(R^{2}\right)=0.87$ and standard error of estimation (SE) $=2.25 \mathrm{~kg}$, where $x_{1}, x_{2}$ and $x_{3}$ represent carcass weight, fat score and conformation score, respectively. Various reliable models also exist to predict meat yield for specific cuts of meat.

The South African (SA) beef description system related to eating quality has evolved over a number of years since 1932. Age of the animals has been used since 1936 as a characteristic to grade carcasses, presumably because carcasses of younger cattle were considered to be of 'better' quality than those of older cattle (Government Notice No. 1548 of 1936). The number of permanent incisors was used for the first time in 1949 when 'A' designated carcasses of younger animals with not more than 6 permanent incisors and 'B' designated carcasses of older animals with more than 6 permanent incisors, but which were not older than four years (Government Notice No. 992 of 1949). Klingbiel (1984) found that A-age animals had significantly higher muscle collagen solubility, that muscle pigment concentration was significantly lower, and that the cooking loss (\%) was significantly lower. These results could be generalised by saying that the meat of A-age animals (not more than 2 permanent incisors) was more tender, lighter coloured and juicier than meat from older animals. After a series of discussions held by various working groups and committees, a proposal was accepted to define the age classes as A: having 0 permanent incisors; B: 1 to 6 permanent incisors; and C: 7 to 8 permanent incisors (Government Notice No. R.1010 of 1981). In subsequent years various alterations were applied to the system until the current classification system was implemented in 1996 after the work of Crosley et al. (1994) confirmed previous work and showed that meat tenderness decreased as the slaughter age of the animals increased in the order of 0,2, 4, 6 and 8 permanent incisors (Figure 1). Samples of meat from animals with no permanent incisors were significantly more tender than those of the animals with 2 permanent incisors, and this effect was more pronounced in high connective tissue muscles such as the $m$. biceps femoris (Figure 2). Animals with 2, 4 or 6 permanent incisors were not appreciably different in terms of tenderness. In spite of these results, not all members of industry were convinced and exerted pressure on the authorities to eventually classify carcasses with 2 permanent incisors in a separate age class (AB) than those with 3 to 6 permanent incisors (B) and 0 permanent incisors (A) (Government Notice No. R.342 of 1999). Although the classification system was not intended for the purpose of ranking carcasses, description of 'Most Tender', 'Tender', 'Less Tender' and 'Least Tender' were given to the four age classes, respectively.

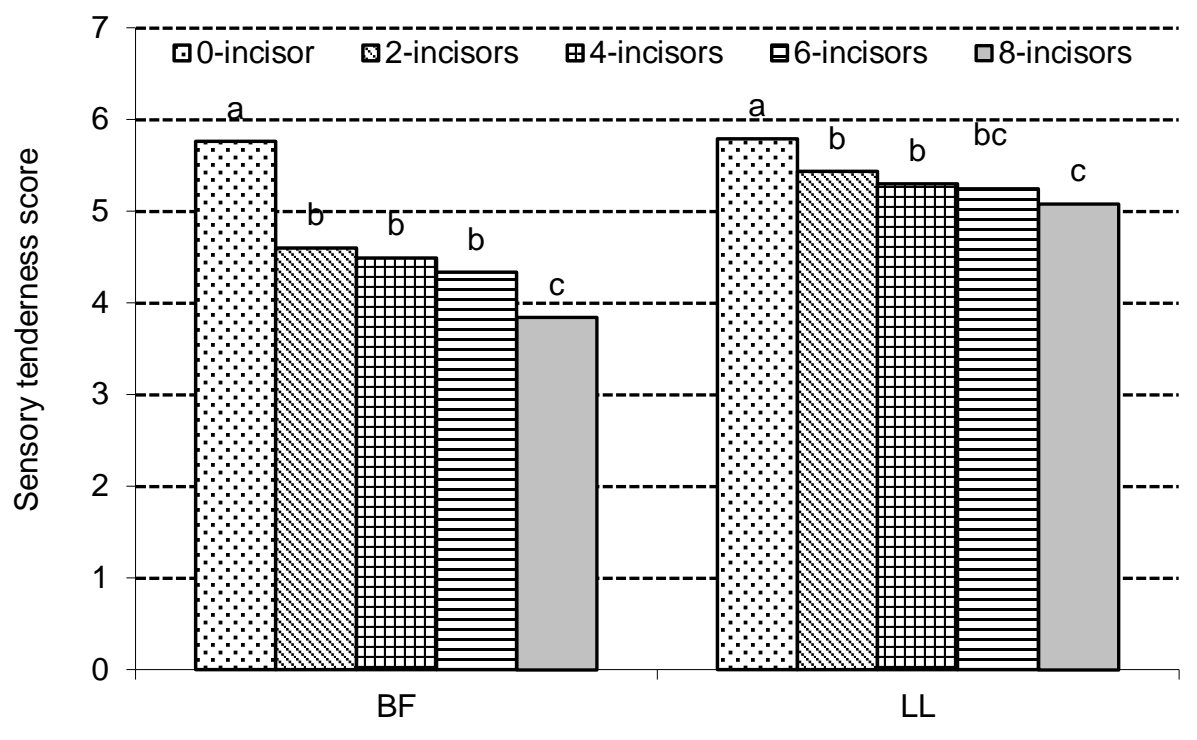

Figure 1 The effect of age class (by dentition) on sensory tenderness scores of $m$. longissimus lumborum (LL) and $m$. biceps femoris (BF) (Crosley et al., 1994). $\left({ }^{a, b, c}\right.$ Bars with different superscripts differ significantly $(P<0.05)$. Sensory tenderness: 1 - extremely tough; 8 - extremely tender). 


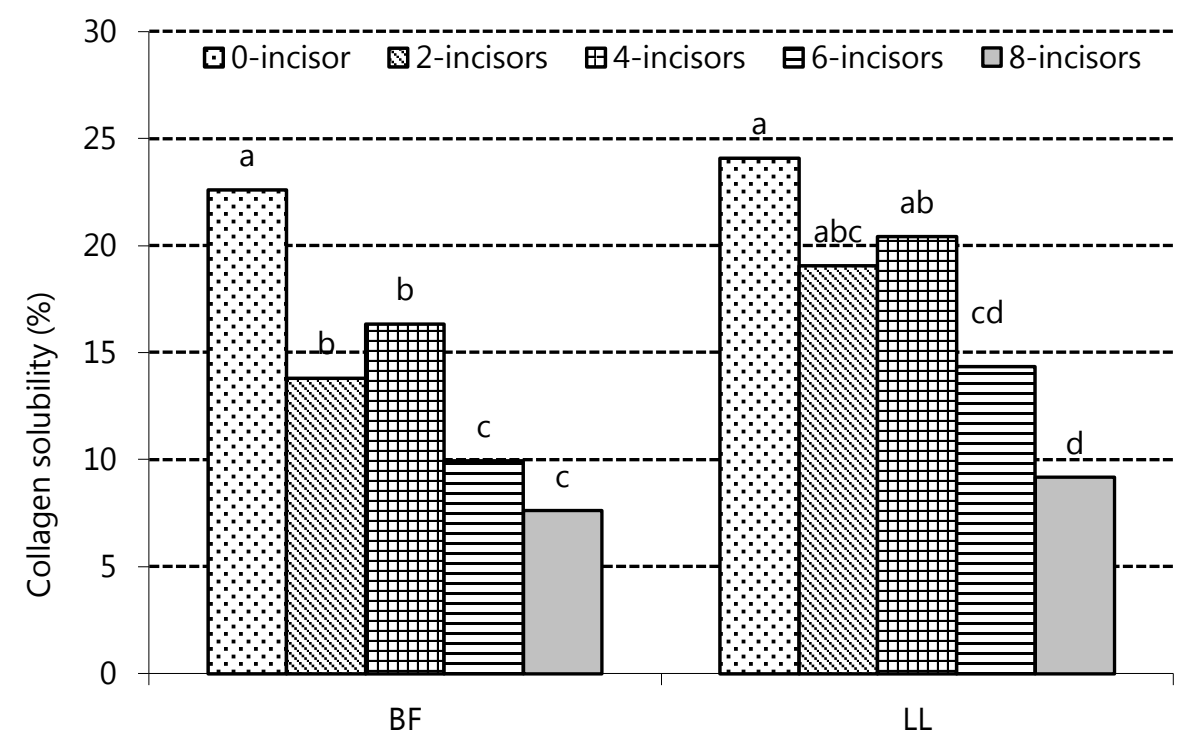

Figure 2 The effect of age class (by dentition) on collagen solubility (\%) of $m$. longissimus lumborum (LL) and m. biceps femoris (BF) (Crosley et al., 1994). $\left({ }^{\mathrm{a}, \mathrm{b}, \mathrm{c}, \mathrm{d}}\right.$ Bars with different superscripts differ significantly $\left.(P<0.05)\right)$.

Shorthose \& Harris (1990) also reported on the effects of animal age on tenderness of different muscle types. While deep breast muscle ( $m$. pectoralis profundus) and some muscles from the buttock ( $m$. gluteobiceps and $m$. semitendinosus of the silverside) were unacceptably tough before 2 years of age, the $m$. vastus lateralis and $m$. rectus femoris of the knuckle and $m$. semimembranosus, $m$. gracilis and $m$. aductor femoris of the topside became unacceptable after 2 years of age. The tenderness of loin ( $m$. longissimus) (LD), fillet ( $m$. psoas major) and rump ( $m$. gluteus medius and top $m$. gluteo biceps) was acceptable up to 48 months of age which coincided with 6 to 8 permanent incisors. The benchmark for acceptability is of course ambiguous but nevertheless this work demonstrates the relative effect of age on tenderness. Shorthose \& Harris (1990) also found that the LD is a very poor muscle to use as a reference for the prediction of tenderness. Another South African study completed at the same time as the work of Crosley et al. (1984), but published recently, confirmed an age-related increase in heat-stability of connective tissue (collagen; Figure 2) and that the higher the collagen content of a cut, the more it will be affected by age even when the correct cooking method is used (moist heat cooking) and even when the collagen solubility is high (Schönfeldt \& Strydom, 2011).

The general motivation to use age as a descriptor for variation in quality, particularly tenderness, was very valid at the time when the classification system was implemented. The classification system was developed and applied in a highly regulated industry and was designed for very specific existing conditions. Various policies, such as the distinction between controlled and uncontrolled areas, compulsory levies payable by producers, restrictions on the establishment of abattoirs, the compulsory auctioning of carcasses according to grade and mass in controlled areas, the supply control via permits and quotas, the setting of floor prices, removal scheme, etc., characterised the red meat industry before deregulation commenced in the early 1990's (Jooste, 1996). Production systems (e.g. feedlots: diet, growth enhancers, feeding duration) were fairly standardised and about $60 \%$ of all carcasses slaughtered were of the A age class, probably originating from feedlots. In addition, due to controlled and uncontrolled areas, more than $60 \%$ of cattle were slaughtered in state owned abattoirs (Abattoir Corporation; ABAKOR) in regulated areas under standardised pre-slaughter, slaughter and post-slaughter conditions. It is safe to say that sources of variation in quality of beef would have been limited, at least in comparison to current conditions. Since the deregulation of the agricultural marketing dispensation in 1997, many changes have occurred in all sectors of the industry. Today feedlots produce more than $80 \%$ of beef in the formal sector. Many feedlots converted to vertically integrated systems consisting of back grounding units, feedlots, abattoirs and processing plants and some even branched out into retailing their own branded product. It is estimated that $60 \%-80 \%$ of animals going through feedlots are slaughtered by vertically integrated abattoirs. Larger abattoirs (Class A and B; 50 to $100+$ carcasses per day) still provide $60 \%$ of all carcasses, but now their operations are controlled 
individually. In addition, many smaller abattoirs also exist, each with their own operational procedures and facilities such as electrical stimulation and chilling. Many changes have also occurred in the production of animals that could affect the final quality of the product.

\section{Sources of variation in quality of South African beef according to case studies}

While age by dentition is the only quality related criterion in the SA classification system, sufficient evidence exists to show that factors other than age (extrinsic or intrinsic) may have an effect on tenderness. These factors may even overshadow the effect of age depending on the type of muscle and include various pre-slaughter, slaughter and post-slaughter conditions and procedures (Ferguson et al., 2001). In two recent studies, effects of age, production system (including nutrition) and abattoir practice on tenderness were investigated (Van Wyk et al., 2008; Frylinck et al., 2009) (Figure 3).

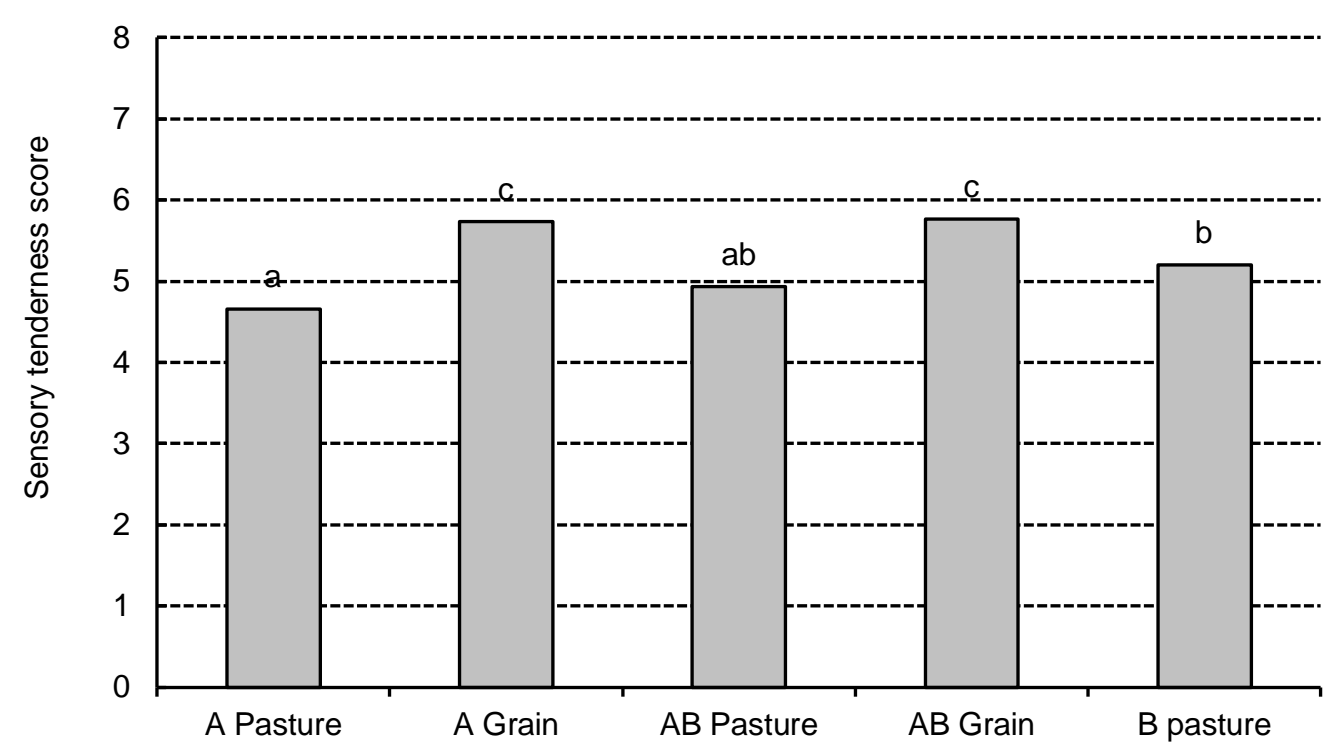

Figure 3 The effect of age class (by dentition) and production system on sensory tenderness scores of $m$. longissimus lumborum (Van Wyk et al., 2008; Frylinck et al., 2009).

$(A=0$ incisors; $A B=1-2$ permanent incisors; $B=3-6$ permanent incisors.

$\mathrm{a}, \mathrm{b}, \mathrm{c}$ Bars with different superscripts differ significantly $(P<0.05)$.

Sensory tenderness: 1 - extremely tough; 8 - extremely tender).

Loin steaks of carcasses of feedlot animals with either 0 (Class A) or 1 to 2 (Class AB) incisors were more tender (sensory panel and Warner-Bratzler shear force) than loin steaks of carcasses from pasture animals aged according to incisors from 0 to 6 or $A-, A B-$ and B-age classes. Among the pasture animal groups, animals with no permanent incisors (A-class) produced tougher steaks than animals with 3 to 6 incisors (B-class) and animals with 3 to 6 incisors had numerically better tenderness scores than animals with 1 to 2 incisors (AB-class). The poor performance of the very young pasture animals (A-class) could be related to poorly conditioned small carcasses, reflecting poor growth rate which were chilled more rapidly and therefore were prone to cold shortening of the loin although electrical stimulation was applied. Shackelford et al. (1994) and Perry \& Thompson (2005) reported more tender meat from faster growing animals within the same group, which Shackleford et al. (1994) related to lower calpastatin activity which could lead to better muscle ageing ability. Purchas et al. (2002) recorded similar effects and stated that growth path (i.e. growth rate determined by feeding) or growth potential (genetic) had the same effect, namely, slow growers resulted in older animals and poorer carcass condition. Interestingly they also showed that fast growers had an advantage in ageing potential but gave no results on connective tissue properties and its relationship to tenderness differences. Although the current volumes for A-class pasture reared animals and AB-class in general (pasture and grain fed; $4 \%$ market share) are very low compared to A-class 
grain fed animals, the results from the present study are important, as they indicate that feeding regime may have an effect on meat quality within the same age class.

Hormonal growth promotants (HGPS) are widely used in the feedlot industry that represents the largest portion of carcasses produced in the South African market. Studies have shown variable effects on tenderness and eating quality, but differences are often small and difficult to measure, and are influenced by the number and type of HGPs used, animal breed and the duration and type of post-slaughter treatment such as ageing (Hunter, 2010). It was, however, concluded by Watson et al. (2008) and Hunter (2010), in controlled studies, that HGPs do have a negative effect especially with repeated applications, combination of substances and aggressiveness of substances.

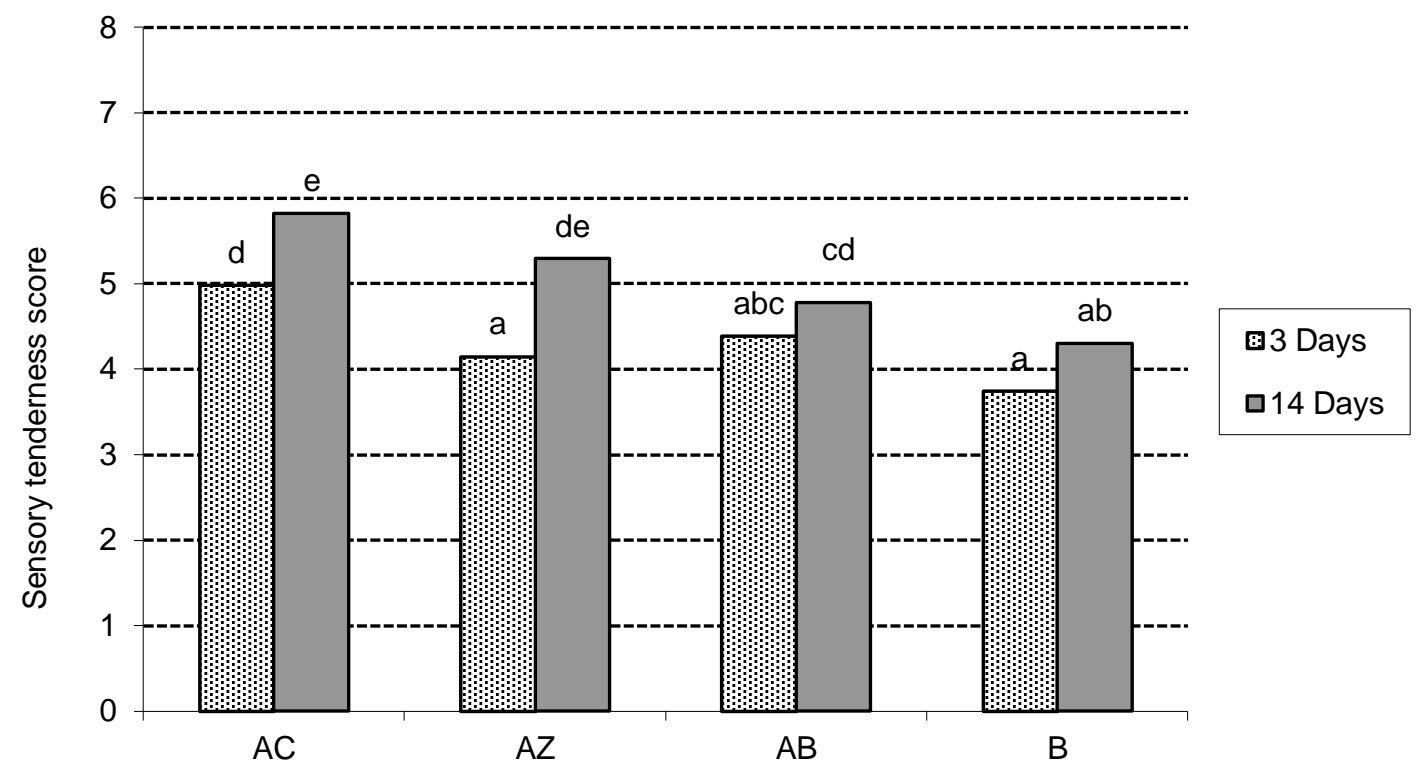

Figure 4 Sensory tenderness values of $m$. longissimus lumborum from 4 age/treatment groups at 3 and 14 days post mortem.

$\left({ }^{a, b, c}\right.$ Bars with different superscripts differ significantly $(P<0.05)$.

Sensory tenderness: 1 - extremely tough; 8 - extremely tender.

$A C=A$-age with no zilpaterol treatment, grain fed; $A Z=A$-age with zilpaterol treatment, grain fed; $A B=A B$-age, pasture reared; $B=B$-age, pasture reared).

Judged by the magnitude of their effects, the use of beta agonists (always in combination with HGPs) that were only introduced in the late nineteen nineties to early 2000 s, has a much greater negative effect on eating quality (tenderness specifically) (Dunshea et al., 2005) and while proper management of the rigor process (electrical stimulation, chilling) and post mortem ageing overcome most HGPs' effect, this is not achieved with beta agonists (Hope-Jones et al., 2010). As beta agonists are mostly used in feedlots, they are most likely to cause increased variation in quality within the A-age class. This was not evident in the studies of Van Wyk et al. (2008) and Frylinck et al. (2009) reported in Figure 3, as no beta agonist was used in these studies. Interestingly, a recent study by Moholisa et al. (2013) could not find significant differences in sensory tenderness scores and shear force between loin steaks of A-age animals supplemented with zilpaterol (a beta agonist) and steaks of $A B$ - and B-age pasture reared cattle when samples were aged for three days. In agreement with the study of Crosley et al. (1994) A-age samples from non-zilpaterol animals were more tender than those of all other age groups (Figure 4). When the steaks were aged for 14 days, zilpaterol steaks improved more in sensory score than steaks of $A B$ - and B-age carcasses, but were still not significantly more tender than $A B$-age steaks and slightly less tender than non-zilpaterol A-age steaks. According to Figure 5, the effect of zilpaterol was not significant in the high connective tissue, $m$. biceps femoris, and the expected differences between age groups as previously reported by Crosley et al. (1994) were found. Beta agonists increase calpastatin activity thereby impairing calcium induced proteolysis and causing tougher loin cuts in the initial and also often in the final stages of ageing (Strydom et al., 2009, 2011). In the study of Moholisa et al. (2013) the effect of higher calpastatin in the A-age animals' loin 
muscles was therefore equal to the effect of connective tissue in loin cuts of older cattle (AB and $B)$, but was mostly overcome by prolonged ageing. Since most feedlots use a beta agonist, this type of variation is expected and when compared to the few feedlots that do not use beta agonists, variation within the A-age low connective tissue cuts could be large, in particular when duration of ageing is also considered.

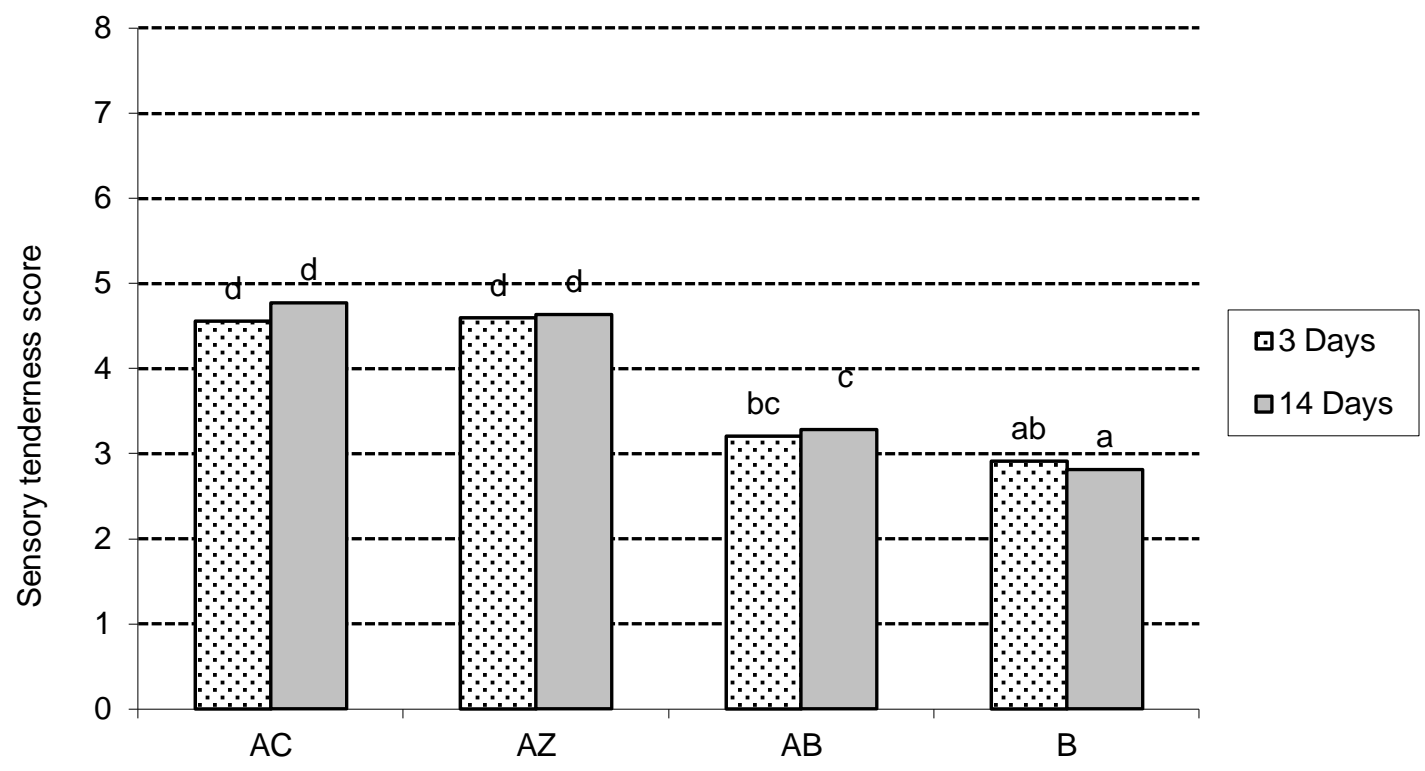

Figure 5 Sensory tenderness values of $m$. biceps femoris from four age/treatment groups at 3 and 14 days post mortem.

$\left({ }^{a, b, c} \mathrm{~B}\right.$ Bars with different superscripts differ significantly $(P<0.05)$.

Sensory tenderness: 1 - extremely tough; 8 - extremely tender.

$A C=A$-age with no zilpaterol treatment, grain fed; $A Z=A$-age with zilpaterol

treatment, grain fed; $A B=A B$-age, pasture reared; $B=B$-age, pasture reared).

When the variation in procedures before, during and after slaughter is considered, the problem becomes more complex. Electrical stimulation has been discussed in relation to age but its true effect is only revealed when both the comparisons of stimulation vs. no stimulation and the correct application of stimulation are taken into account. Referring back to the state-owned abattoirs of two decades ago, the slaughter process (including stimulation) was standardised, while today various scenarios (no stimulation, ineffective stimulation, over stimulation) may occur due to a highly deregulated abattoir industry. The impact of this state of affairs is demonstrated by various studies (Hwang \& Thompson, 2001a; b; Hwang et al., 2003; Strydom et al., 2005; Strydom \& Frylinck, 2014). Strydom et al. (2005) and Strydom \& Frylinck (2013) demonstrated that no stimulation will produce less tender loin steaks when compared to any stimulation treatment, in particular when meat is not aged for long durations (Figure 6). However, the study of Strydom \& Frylinck (2013) also showed that 'over stimulation' (duration of 90 seconds or even 45 seconds) gave poorer shear force values compared to 15 second stimulation duration. The negative effects of over stimulation and no stimulation were more evident with shorter ageing times, conditions that occur commonly in the South African industry. It should be noted that it is not the specific duration of stimulation that is critical for best quality but rather the rigor conditions created by a particular stimulation and chilling regime. Thompson (2002) described so-called 'high rigor temperature' conditions where muscle temperature exceeds $35^{\circ} \mathrm{C}$ when a pH $=6$ is reached (onset of rigor). Under these conditions excessive protein denaturation takes place leading to inactivation of calpains due to increased autolysis and consequent impairment of the ageing potential of muscle.

Hope-Jones et al. (2010) studied the combined effect of beta agonist supplementation, slaughter practice (electrical stimulation) and post slaughter practice (ageing) on meat tenderness related properties. Figure 7 shows that different combinations of either using zilpaterol or not, or using electrical stimulation, or not, and shorter and longer duration of ageing could produce loin steaks of vastly different tenderness values 


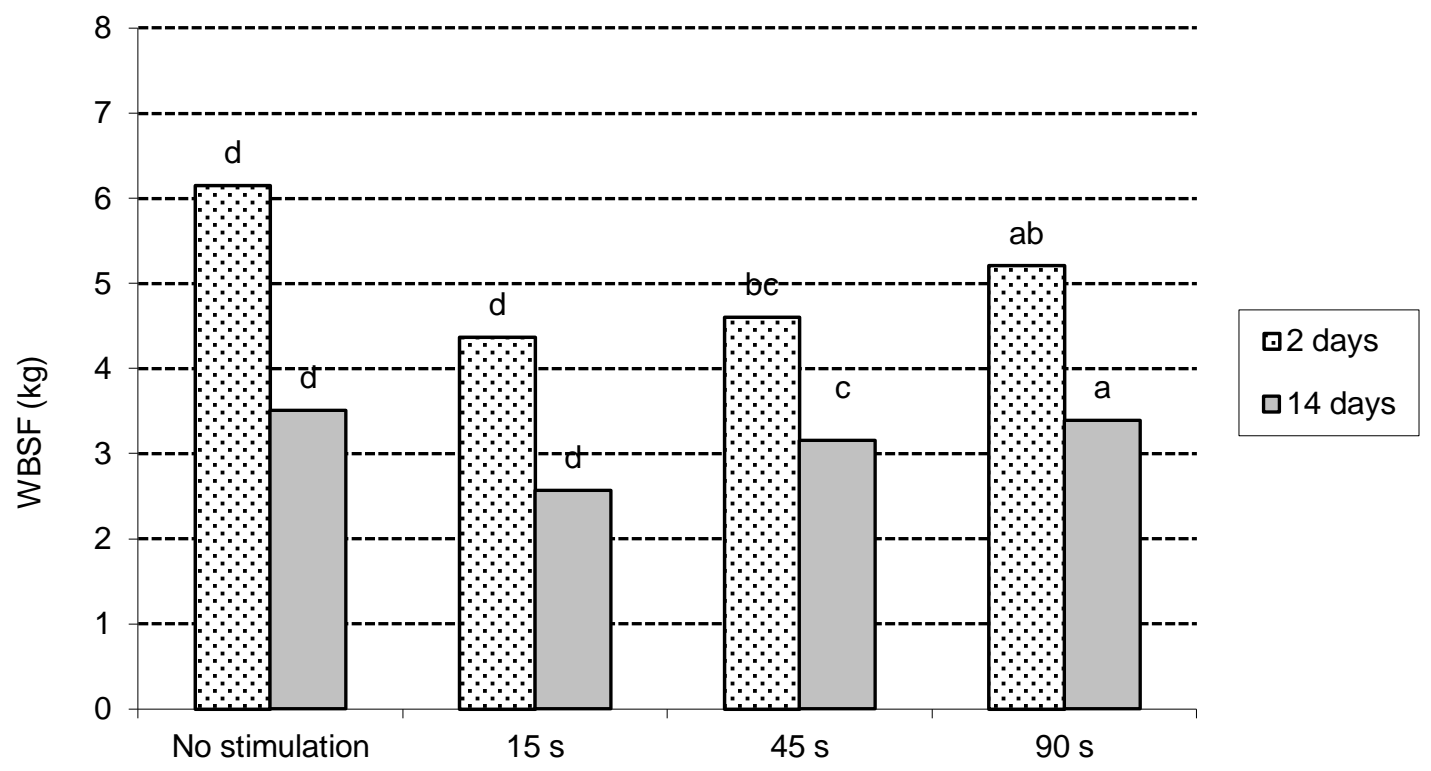

Figure 6 Interaction between electrical stimulation treatment and post mortem ageing for Warner-Bratzler shear force (WBSF) of $m$. longissimus lumborum.

(No electrical stimulation was applied or low voltage electrical stimulation was applied for $15 \mathrm{~s}, 45 \mathrm{~s}$ and $90 \mathrm{~s}$, respectively. Samples were aged for 2 or 14 days post mortem. $\mathrm{a}, \mathrm{b}, \mathrm{c}, \mathrm{d}$ Bars with different superscripts differ significantly $(P<0.05))$.

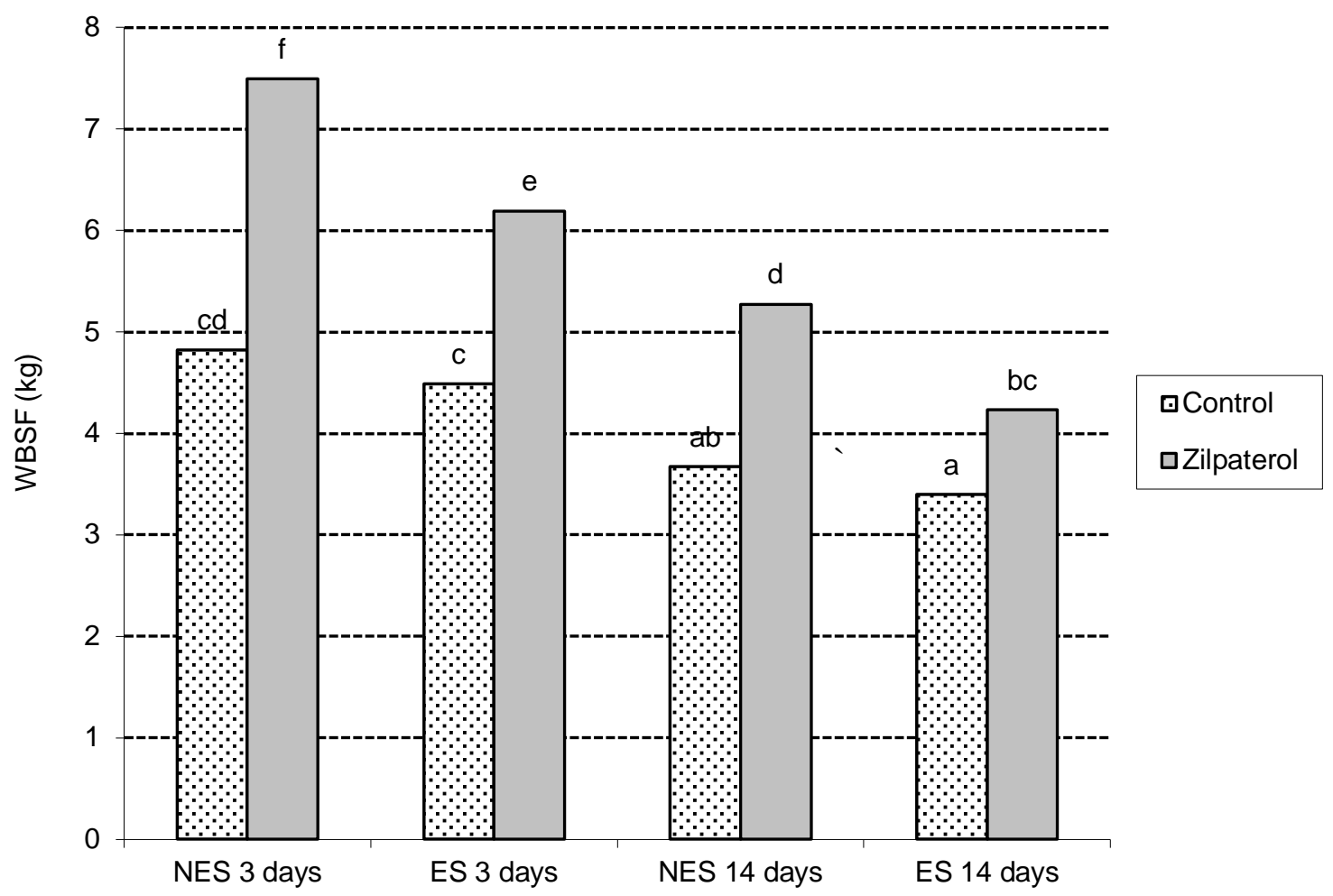

Figure 7 Interaction between treatment (control and zilpaterol), electrical stimulation and post mortem ageing ( 3 and 14 days) in relation to Warner-Bratzler shear force (WBSF) of $m$. longissimus lumborum.

$\left({ }^{a}, \mathrm{~b}, \mathrm{c}, \mathrm{d}\right.$ Bars with different superscripts differ significantly $(P<0.05)$.

ES and NES = stimulated and non-stimulated, respectively). 
within A-age carcasses. The worst scenario was created when zilpaterol was used (as most feedlots do) together with no stimulation and post mortem ageing was limited to three days. The application of electrical stimulation and post mortem ageing benefits the zilpaterol treated samples more than the zilpaterol free samples, although untreated samples still had a significantly improved tenderness even after prolonged ageing and electrical stimulation. These four scenarios further emphasis the degree of variation in tenderness that can possibly be created on a retail level. Electrical stimulation and ageing can, however, be regarded as reliable tools to minimise variation and contribute to consistency.

Certain local feedlot operations recently experimented with ultra-high levels of vitamin $D_{3}$ to overcome the negative effect of beta agonists on tenderness. These efforts stemmed from the studies of Montgomery et al. (2002), Montgomery et al. (2004a) and others that demonstrated that high levels of vitamin $\mathrm{D}_{3}$ supplement during the final days of feeding could increase plasma calcium levels by stimulating intestinal calcium absorption, mobilizing calcium from bone minerals and increasing renal reabsorption of calcium (as reviewed by Swanek et al., 1999). Higher blood and muscle calcium would lead to increased activation of the calpains and improved tenderness (Karges et al., 2001; Montgomery et al., 2002; Montgomery et al., 2004b). However, the studies conducted by Strydom et al. (2011) and Korn et al. (2014) demonstrated that high vitamin $D_{3}$ supplements before slaughter did not alleviate the tenderness problem caused by zilpaterol and may have even increased the toughness of loin steaks.

\section{Tenderness variation in beef loin steaks at retail level}

It is evident that various processes at different stages of the meat value chain contribute to variation in quality of the final product, in particularly meat tenderness. While there is no formal study to verify if variation in quality was already present two decades ago, it is worthwhile knowing what the current state of affairs is like. To that end a survey was conducted at 14 retail outlets in the Pretoria region (Strydom et al., 2012; 2013). Various butcheries and large retail stores were sampled and cuts known as 'porterhouse steaks', mainly consisting of the $\mathrm{m}$. longissimus lumborum, were used in the survey. Twenty one products were purchased over six month on 20 occasions at the same stores. In other words various forms of the same product were purchased at some stores and these differences were mostly related to packaging type. At certain outlets, both vacuum packaged and conventionally packaged steaks were available - conventional in this case meaning steaks presented on Styrofoam trays overwrapped with poly-vinyl-chloride film (PVC). In some cases more than one vacuum packaged product was available. For some products certain quality claims were made, mostly related to how long the ageing process has been. Various quality characteristics were measured but in this paper only Warner-Bratzler shear force (WBSF) will be reported and related to the price of the product. Figure 8 ranks the products according to the mean WBSF value of 20 samples per product from the highest to the lowest value. The codes for the various products are described with ' $\mathrm{B}$ ' and ' $R$ ' when the outlet was either a butcher (mainly selling meat) or large retailer (selling all kinds of food and household products). The letters, ' $V$ ' and ' $F$ ', represent products that were vacuum packaged or not (fresh) and the number indicates the specific outlet. Common numbers for different products therefore, indicate different products from the same store. The different products were benchmarked against two WBSF values, namely $3.9 \mathrm{~kg}$ and $4.6 \mathrm{~kg}$ which Shackelford et al. (1991) regarded as critical values for products suitable for 'Food service' and 'Retail', respectively. Thirteen of the 21 products had mean WBSF values $(n=20)$ above $4.6 \mathrm{~kg}$ and 16 had values above $3.9 \mathrm{~kg}$. The difference between the most tender and toughest product was $4.9 \mathrm{~kg}$. Products from larger retailers and also vacuum packaged products tended to be more tender. Generally speaking, more tender products were also more expensive. However, when considering price, packaging and products from the same outlets in more detail, it is evident that no specific relationship existed between these three factors. For example, B4F and B4V were almost similar in price and in tenderness. In contrast B1F was much cheaper than B1V, yet the latter was not significantly more tender, while B7V was more expensive than B7F and more tender. B3V and B3F were sold at the same price, yet the vacuum packed cut was more tender, probably suggesting longer ageing. The same applied to Retailer 4 , where the vacuum packaged and fresh product had the same price, but the former was more tender. Retailer 2 sold a vacuum packaged product at a higher price but it was also more tender than the fresh product (probably not aged extensively). The vacuum packaged product of B2V is worth mentioning as it had the second lowest price after the toughest product, but it was ranked eighth in tenderness. All products originated from A-age grain fed cattle except for R3FR that was grass fed and aged for more than 35 days. This product was also the most expensive.

In addition to the huge variation within and among retailers, it was also significant that variation within the same product was often very high. Figure 9 demonstrates the chances of finding a good steak when a consumer shops for the same product on 20 occasions at two different outlets. When shopping at Retailer 1 , the chances of finding at least a fairly tender $(<4.2 \mathrm{~kg})$ were 12 out of 20 . In contrast, have the purchases been made at Retailer 2 , only one out of 20 steaks would have satisfied. In addition the product sold by 
Retailer 2 was $7 \%$ more expensive than the product sold by Retailer 1, so buying steaks from Retailer 2 would be a great risk for any consumer.

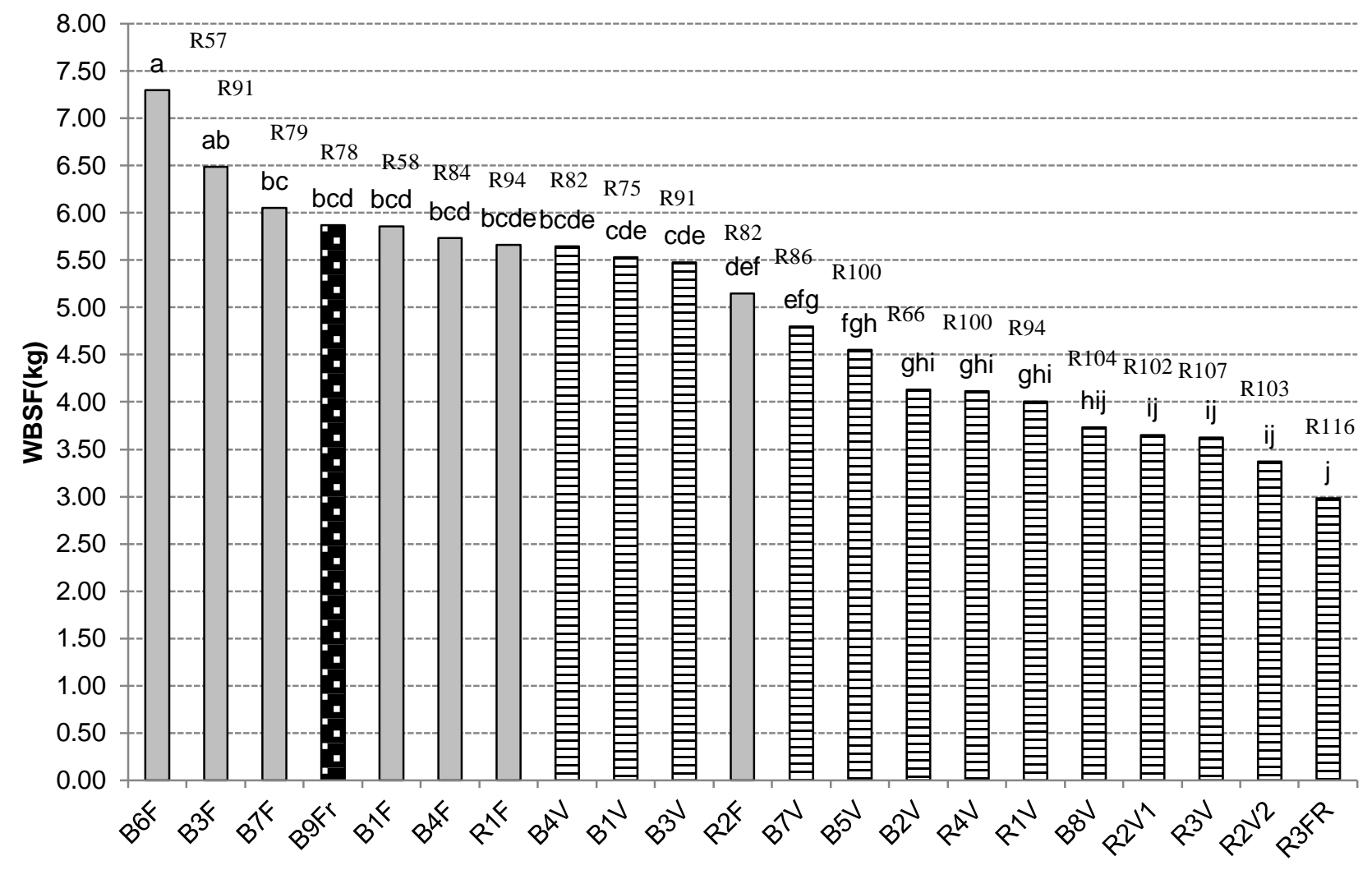

Figure 8 Ranking of mean Warner-Bratzler shear force values of 21 porterhouse steak products purchased on 20 different occasions from 14 outlets.

(Outlets were either butchers (B) or large retail outlets (R); ' $V$ ' indicates vacuum packaged and ' $F$ ' describe steaks displayed on Styrofoam trays overwrapped with PVC film or displayed open in trays behind the counter; 'FR' represents 'Free Range' and 'Fr' represents frozen product; Price per kg is in ZAR.

$\mathrm{a}, \mathrm{b}, \mathrm{c}, \mathrm{d}$ Bars with different superscripts differ significantly $(P<0.05))$.

It is probably safe to conclude that the South African classification system at present distinguishes between feedlot animals (mostly A-age, with $1 \%-2 \%$ AB-age animals and very few A-age pasture animals), younger pasture animals ( $\mathrm{AB}$-age), older pasture animals (B-age) and cull animals ( $\mathrm{C}$-age). When all the studies describing various sources of tenderness are considered, it is evident that the sources of variation in tenderness are much broader than can be described by age alone, in particular within the A-age grain fed product. Although the general definition of classification is that it only describes according to certain measurements or scores and does not rank carcasses according to quality and price, the probability of experiencing a 'bad steak' (specifically referring low connective tissue cuts) in the A-class (feedlot) has probably increased since the implementation of the current South African classification system. However, the fact that the classification system indirectly distinguishes between pasture- and grain-fed animals may be more relevant when referring to the tenderness of cuts which are particularly high in connective tissue (Crosley et al., 1994). In addition, to distinguish between pasture- and grain-fed animals is relevant when other quality characteristics are considered, such as fat colour and flavour. Wood et al. (2003) and Campo et al. (2006) reported that the fatty acid compositions of pasture and grain fed animals differ and that these differences relate to differences (not preferences) in taste (flavour, juiciness, aroma). Sañudo et al. (1998) described the significance of culinary cultural background in relation to the acceptance of meat produced from pasture or feedlots, thereby indicating preferences for flavour or taste based on experience. These studies emphasised the fact that the description (through classification) of two products that could be experienced differently by different consumers but without one-sided preference, is probably the main 


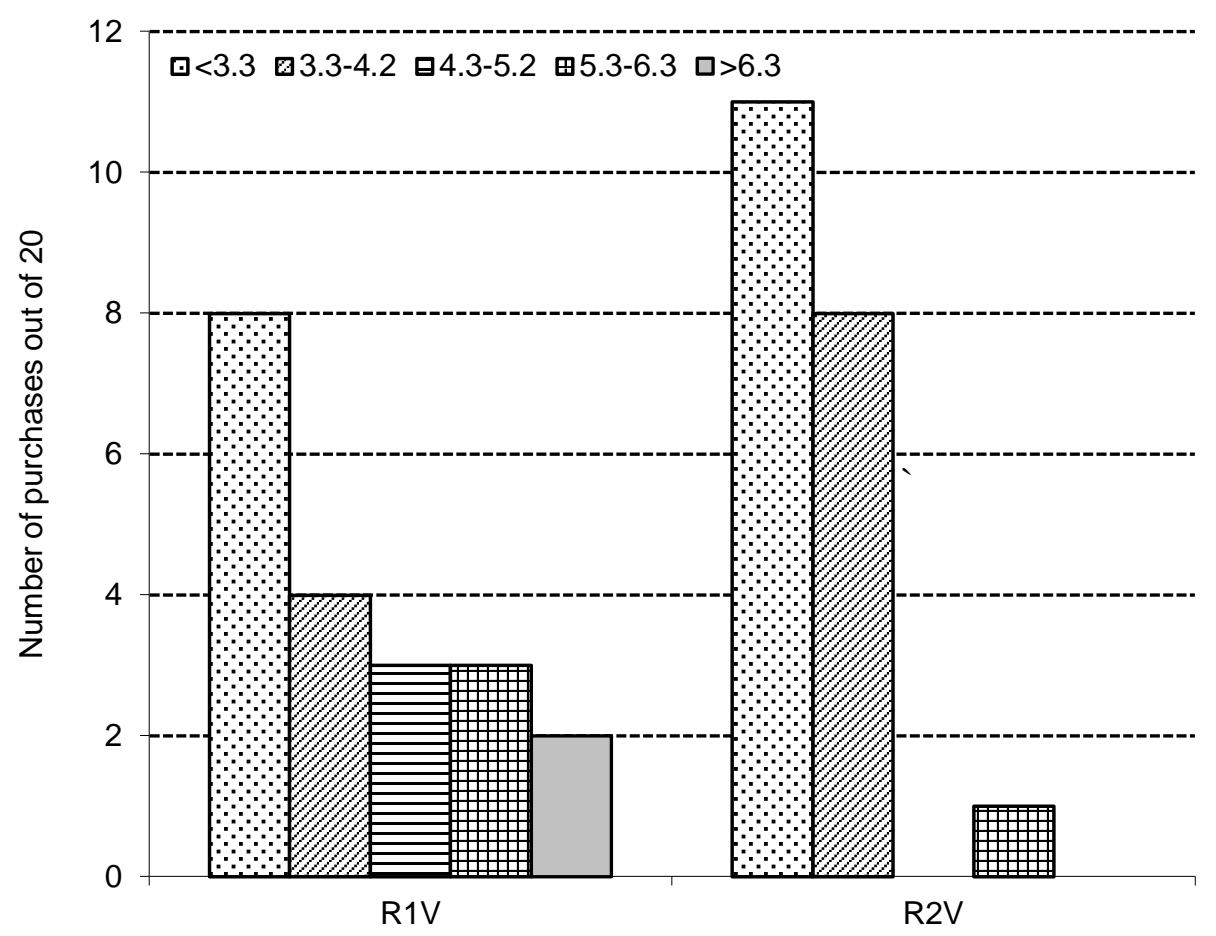

Figure 9 The number of chances out of 20 purchase opportunities to have success (WBSF $<4.2 \mathrm{~kg}$ ) or failure (WBSF $>5.2$ ) when purchasing porterhouse steak from two retail outlets.

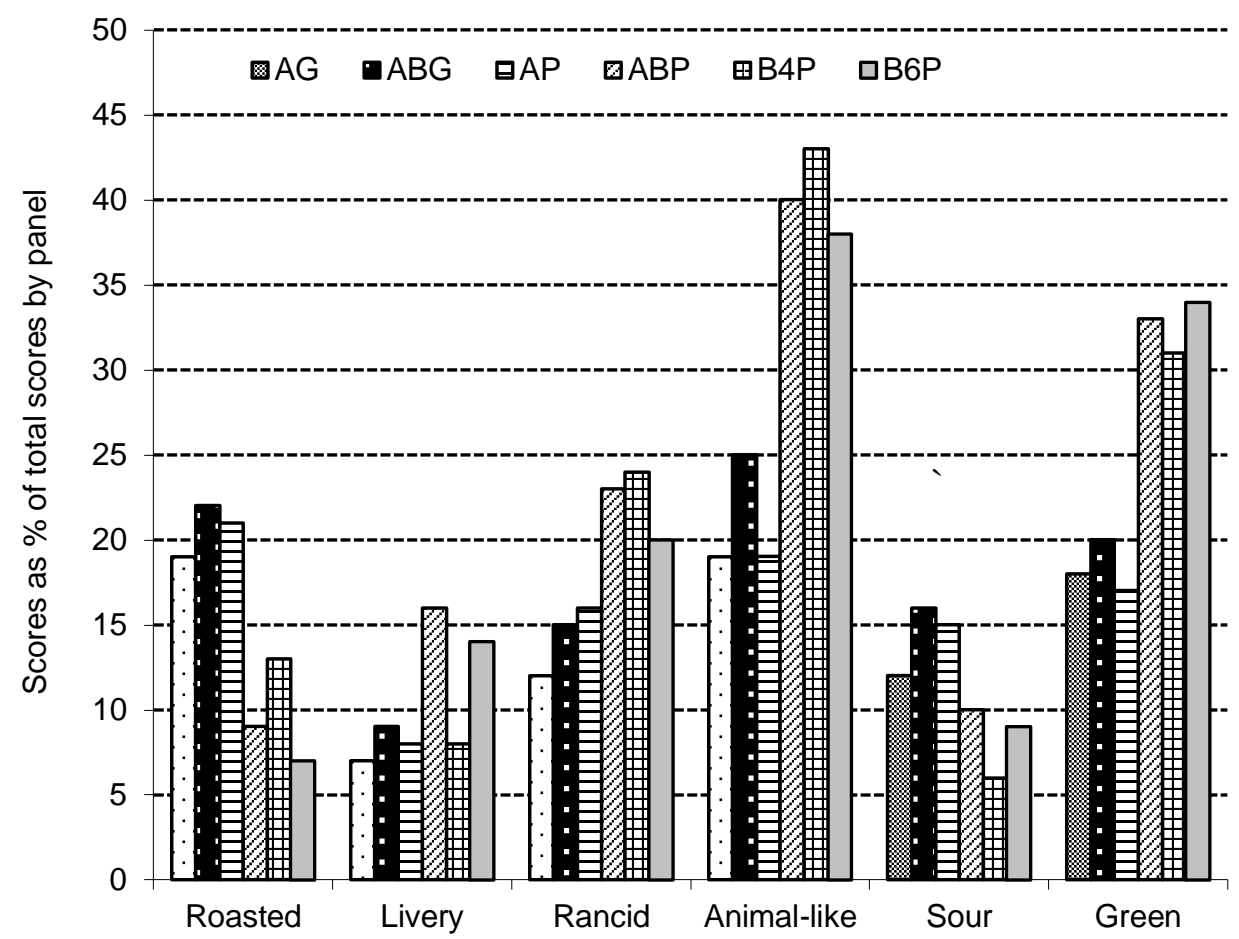

Figure 10 Frequencies of scores for different flavour overtones noted in loin cuts of different age and feeding regime groups. (Frequencies indicate the number of times a specific attribute was noted in a steak by a 10 member sensory panel as \% of total steaks (10 per group) tested by all members - 100 opportunities; Age groups $A, A B, B 4$ and $B 6$, respectively, indicating $0,2,4$ and 6 permanent incisors; Feeding regime described as ' $G$ ' for grain-fed and ' $P$ ' for pasture-reared). 
objective of classification if variation in consumer preferences is expected. The study of Strydom et al. (2013b) clearly showed that flavours such as 'animal-like', 'rancid' and 'grassy' or 'green' were more likely to be noticed in loin cuts of older pasture reared cattle ABP, B4P and B46P than in loin cuts of young grain fed $(A G)$ and pasture reared (AP) and slightly older grain fed (ABG) cattle (Figure 10). The problem in the current classification system in this regard is that $A B$ class animals on different feeding regimes may produce a completely different product with regard to taste.

\section{Acknowledgements}

Mrs Yolande van Rooyen for her great effort in the technical preparation of this document.

\section{References}

AHDB Industry Consulting, 2008. Review of the EU Carcass Classification System for Beef and Sheep.

Campo, M.M., Nute, G.R., Hughes, S.I., Enser, M., Wood, J.D. \& Richardson, R.I., 2006. Flavour perception of oxidation in beef. Meat Sci. 72, 303-311.

Crosley, R.I., Heinze, P.H. \& Naudé, R.T., 1994. The relationship between beef tenderness and age classification in the South African Beef carcass classification system. Proc. 40th Int. Cong. Meat Sci. Technol., The Hague, Netherlands S-III. 15, 34-35.

Dunshea, F.R., D'Sousa, D.N., Pethick, D.W., Harper, G.S. \& Warner, R.D., 2005. Effect of dietary factors and other metabolic modifiers on quality and nutritional value of meat. Meat Sci. 71, 8-38.

Ferguson, D.M., Bruce, H.L., Thompson, J.M., Egan, A.F., Perry, D. \& Shorthose, W.R., 2001. Factors affecting beef palatability - farm gate to chilled carcass. Aus. J. Exp. Agric. 41, 879-891.

Frylinck, L., Strydom, P.E. \& Snyman, J.D., 2009. Subcutaneous fat colour - an indication of beef eating quality? Proc. 55th Int. Cong. Meat Sci. Technol., 16-21 August 2009, Copenhagen, Denmark, PE 7.43 .

Government Notice No. 1548 of 16 October 1936. Grading of agricultural produce in Johannesburg. Government Gazette of the Union of South Africa. 106 (2385), 1-12.

Government Notice No. 992 of 20 May 1949. Grading and marking of meat. - Amendment. Extraordinary Government Gazette of the Union of South Africa (24/03/2010)

Government Notice No. R.1010 of 8 May 1981. Regulations regarding the classification, grading and marking of meat which is intended to be sold in the Republic of South Africa. Government Gazette of the Republic of South Africa 191 (7573) (Regulation Gazette No. 3191) 2-14.

Government Notice No. R.342 of 19 March 1999. Regulations regarding the classification and marking of meat. Government Gazette of the Republic of South. Africa, 19 March 1999. pp. 5-6.

Hope-Jones, M., Strydom, P.E., Frylinck, L. \& Webb, E.C., 2010. The efficiency of electrical stimulation to counteract the negative effects of $\beta$-agonists on meat tenderness of feedlot cattle. Meat Sci. 86, 699-705.

Hunter, R.A., 2010. Hormonal growth promotant use in the Australian beef industry. Anim. Prod. Sci. 50, 637-659.

Hwang, I.H. \& Thompson, J.M., 2001a. The effect of time and type of electrical stimulation on the calpain system and meat tenderness in beef longissimus dorsi muscle. Meat Sci. 58, 135-144.

Hwang, I.H. \& Thompson, J.M., 2001b. The interaction between $\mathrm{pH}$ and temperature decline early postmortem on the calpain system and objective tenderness in electrically stimulated beef longissimus dorsi muscle. Meat Sci. 58, 167-174.

Hwang, I.H., Devine, C.E. \& Hopkins, D.L., 2003. The biochemical and physical effects of electrical stimulation on beef and sheep meat tenderness. Meat Sci. 65, 677-691.

Jooste, A., 1996. Regional Beef Trade in Southern Africa. MSc thesis, University of Pretoria, Pretoria, South Africa.

Karges, K., Brooks, J.C., Gill, D.R., Breazile, J.E., Owens, F.N. \& Morgan, J.B., 2001. Effects of supplemental vitamin $\mathrm{D}_{3}$ on feed intake, carcass characteristics, tenderness, and muscle properties of beef steers. J. Anim. Sci. 79, 2844-2850.

Klingbiel, J.F.G., 1984. Development of a grading system for beef carcasses. DSc (Agric) thesis, University of Pretoria, South Africa.

Korn, K.T., Lemenager, R.P., Claeys, M.C., Engstrom, M. \& Schoonmaker, J.P., 2014. Supplemental vitamin $\mathrm{D}_{3}$ and zilpaterol hydrochloride. I. Effect on performance, carcass traits, tenderness, and vitamin $\mathrm{D}$ metabolites of feedlot steers. J. Anim. Sci. 91, 3322-3331.

Moholisa, E., Strydom, P.E., Hugo, A. \& Hope-Jones, M., 2013. Effect of beta-agonists and age on tenderness of longissimus dorsi and biceps femoris muscles of grassfed and feedlot steers. Proc. 59th Int. Congr. Meat Sci. Technol., Izmir, Turkey, 18 to 23 August 2013. S5-27. 
Montgomery, J.L., Carr, M.A., Kerth, C.R., Hilton, G.G., Price, B.P., Galyean, M.L., Horst, R.L. \& Miller, M.F., 2002. Effect of vitamin $D_{3}$ supplementation level on the post mortem tenderization of beef from steers. J. Anim. Sci. 80, 971-981.

Montgomery, J.L., Blanton, J.R., Horst, R.L., Galyean, M.L., Morrow, K.J., Allen, V.G., Wester, D.B. \& Miller, M.F., 2004a. Effect of supplemental vitamin $D_{3}$ concentration on concentrations of calcium, phosphorus, and magnesium relative to protein in subcellular components of the longissimus and the distribution of calcium within longissimus muscle of beef steers. J. Anim. Sci. 82, 2742-2749.

Montgomery, J.L., King, M.B., Gentry, J.G., Barham, A.R., Barham, B.L., Hilton, G.G., Blanto, J.R., Horst, R.L., Galyean, M.L., Morrow, K.J., Wester, D.B. \& Miller, M.F., 2004b. Supplemental vitamin $D_{3}$ concentration and biological type of steers. II. Tenderness, quality, and residues of beef. J. Anim. Sci. 82, 2092-2104.

Perry, D. \& Thompson, J.M., 2005. The effect of growth rate during back grounding and finishing on meat quality traits in beef cattle. Meat Sci. 69, 691-702.

Purchas, R.W., Burnham, D.L. \& Morris, S.T., 2002. Effects of growth potential and growth path on tenderness of beef longissimus muscle from bulls and steers. J. Anim. Sci. 80, 3211-3221.

Quinn, F., 1999. Tracing the future of meat. Proc. of the World Meat Congr. 12 (2), 1-10.

Sañudo, C., Sanchez, A. \& Alfonso, M., 1998. Small ruminant production systems and factors affecting lamb meat quality. Meat Sci. 49, S29-S64.

Schönfeldt, H.C. \& Strydom, P.E., 2011. Effect of age and cut on tenderness of South African beef. Meat Sci. 87, 206-218.

Shackelford, S.D., Morgan, J.B., Cross, H.R. \& Savell, J.W., 1991. Identification of threshold levels for Warner-Bratzler shear force in beef top loin steaks. J. Muscle Foods 2, 289-296.

Shackelford, S.D., Koohmaraie, M., Cundiff, L.V., Gregory, K.E., Rohrer, G.A. \& Savell, J.W., 1994. Heritabilities and phenotypic and genetic correlations for bovine post rigor calpastatin activity, intramuscular fat content, Warner-Bratzler shear force, retail product yield and growth rate. J. Anim. Sci. 72, 857-863.

Shook, J.N., Van Overbeke, D.L., Scanga, J.A., Belk, K.E., Savell, J.W., Lawrence, T.E., Morgan, J.B., Griffin, D.B., Hale, D.S. \& Smith, G.C., 2008. The National Beef Quality Audit 2005. Phase I. Views of producers, packers and merchandisers on current quality characteristics of the beef industry. Prof. Anim. Sci. 24, 189-197.

Shorthose, W.R. \& Harris, P.V., 1990. Effect of animal age on the tenderness of selected beef muscle. J. Food Sci. 55 (1), 1-8.

Smith, G.C., Tatum, J.D. \& Belk, K.E., 2008. International perspective: characterisation of United States Department of Agriculture and Meat Standards Australia systems for assessing beef quality. Aust. J. Exp. Agric. 48, 1465-1480.

Strydom, P.E. \& Smith, M.F., 2005. Predicting yields of high priced trimmed cuts by means of carcass weight and visual assessments of fat cover and conformation. S. Afr. J. Anim. Sci. 35, 195-205.

Strydom, P.E. \& Frylinck, L., 2014. Minimal electrical stimulation is effective in low stressed and well fed cattle. Meat Sci. 96, 790-798.

Strydom, P.E., Frylinck, L. \& Smith, M.F., 2005. Should electrical stimulation be applied when cold shortening is not a risk? Meat Sci. 70, 733-742.

Strydom, P.E., Frylinck, L., Montgomery, J.L. \& Smith, M.F., 2009. The comparison of three $\beta$-agonists for growth performance, carcass characteristics and meat quality of feedlot cattle. Meat Sci. 81, 557-564.

Strydom, P.E., Hope-Jones, M., Frylinck, L. \& Webb, E.C., 2011. The effects of a beta-agonist treatment, Vitamin $D_{3}$ supplementation and electrical stimulation on meat quality of feedlot steers. Meat Sci. 89, 462-468.

Strydom, P.E., Liebenberg, L., Mosimanyana, L. \& Hope-Jones, M., 2012. South African beef quality audit. 2012. Evaluation of alternative packaging methods for retail beef cuts. Proc. 58th Int. Cong. Meat Sci. Technol., Montreal, Canada, 12-17 August 2012. ICoMST2012paper33.pdf. 4 pp.

Strydom, P.E., Liebenberg, L., Hugo, A. \& Hope-Jones, M., 2013a. A quality survey of beef porterhouse based on packaging, product claims and presentation. Proc 59th Int. Cong. Meat Sci. Technol., Izmir, Turkey, 18-23 August 2013. S5-5.

Strydom, P.E., Sehoole, O.C., Hope-Jones, M. \& Van Heerden, S.M., 2013b. Flavour profiles of loin cuts from carcasses of different age classifications, nutritional backgrounds and aged over two aging periods. Proc. 59th Int. Cong. Meat Sci. Technol., Izmir, Turkey, 18-23 August 2013. Oral presentation O29.

Swanek, S.S., Morgan, J.B., Owens, F.N., Gill, D.R., Strasia, C.A., Dolezal, H.G., Dolezal, H.D. \& Ray, F.K., 1999. Vitamin $D_{3}$ supplementation of beef steers increases longissimus tenderness. J. Anim. Sci. 77, 874-881. 
Thompson. J., 2002. Managing meat tenderness. Meat Sci. 62, 295-308.

Van Wyk, G.L., Frylinck, L., Strydom, P.E. \& Snyman, J.D., 2008. Effects of age, pasture- and feedlot conditions on energy metabolism and meat quality. 54th International Congress of Meat Science and Technology. 10-15 August 2008. Cape Town, South Africa.

Watson R., Polkinghorne R., Gee, A., Porter, M., Thompson, J.M., Ferguson, D., Pethick, D. \& Mclntyre, B., 2008. Effect of hormonal growth promotants on palatability and carcass traits of various muscles from steer and heifer carcasses from a Bos indicus-Bos taurus composite cross. Aust. J. Exp. Agric. 48, 1415-1424.

Wood, J.D., Richardson, R.I., Nute, G.R., Fisher, A.V., Camp. M.M., Kasapidou, E., Sheard, P.R. \& Enser, M., 2003. Effects of fatty acids on meat quality: a review. Meat Sci. 66, 21-32. 